\title{
FINANCIAL REFORMS AND THE DECOMPOSITION OF ECONOMIC GROWTH: AN INVESTIGATION OF THE CHANGING ROLE OF THE FINANCIAL SECTOR IN TURKEY
}

\author{
by \\ Öner Günçavd1 ${ }^{*}$ and Suat Küçükçifçi \\ Faculty of Management and \\ Technology and Economic Development Research Centre (TEDRC) \\ Istanbul Technical University \\ 80680 Maçka - Istanbul, Turkey
}

13 August 2002

\begin{abstract}
Turkey undertook a far-reaching structural adjustment programme in 1980. As an integral element of this programme, financial liberalisation aimed at increasing domestic savings and directing them efficiently towards financing investment projects, which will be likely to have positive impacts on economic growth. After 20 years the performance of these reforms in financial markets is still a matter of concern among academics. The aim of this paper is to examine the role of the financial sector in the whole economy and to assess the sources of gross output of the sector. By doing that we are able to connect financial reforms with different source of growth, and analyse the impacts of reforms on the production of financial services in the pre- and pro-liberalisation periods. To accomplish this aim, we introduce a new methodology, which is based upon the Leontief's input-output models. The results imply that the production sector of the Turkish economy has increasingly become independent from the use of financial service produced by the banking and insurance sector particularly in the post-reform period.
\end{abstract}

JEL Classification Key Words
: D57, F14, O16, R15

: Financial reforms, economic growth, input-outputs, Turkey

\footnotetext{
* Corresponding to Öner Günçavdı, Istanbul Technical University, Faculty of Management, Department of Management Engineering, Spor cd. No. 2, 80680 Maçka - Istanbul; Fax: +212-240 72 60; email: guncavdi@itu.edu.tr. Authors are Associate Professor and Assistant Professor respectively.
} 


\section{INTRODUCTION}

The Turkish economy has undergone intense waves of economic problems since the mid-1990, but particularly since the beginning of 2000, when the exchangerate-based disinflation programme was interrupted by two successive financial crises (see Akyüz and Boratav, 2002 and Uygur, 2001). The crises manifested themselves by overvalued domestic currency, unsustainable trade deficits and massive capital outflows as a result, and led the country to facing the severest economic crisis in her history. The financial sector has mainly been considered, by many experts, as responsible for these crisis because of its shallow and fragile structure together with a weak prudential regulation on the banking sector, and because it was not adequate for handling a large surge of financial capital in- and out-flows (e.g. see Yeldan, 2001). However, in the beginning of the 1980s when the government of the time launched financial reforms, the expectation was to create a more efficient and flexible financial system, capable of directing domestic savings to the use of the productive sectors at the lowest cost, and in turn generating economic growth (see, Cizre-Sakallıoğlu and Yeldan, 2000; Arıcanlı and Rodrik, 1990; Celasun and Rodrik, 1989). After nearly 20 years of experience with financially deregulated markets, the Turkish financial sector still appears to raise some concerns, as generating either economic crises or output growth, about its direct/indirect contributions to the Turkish economy.

Some studies in the Turkish literature have evaluated the performance of financial liberalisation (Akyüz, 1990, Ritenberg, 1991, Chhibber and van Wijnbergen, 1992, Uygur, 1993, Atiyas et al., 1993, Günçavdı et al., 1999, 1998 and Günçavdı and Küçükçifçi, 2001). Akyüz (1990), for example, shows that the financial reforms were not accompanied by any significant change in the financing behaviour of the corporations and did not lead to a cheap cost of investment. Regarding the impact of financial liberalisation on investment, Günçavdı et al. (1998) and (1999) argue that the Turkish economy has benefited from the reform policies in the long run by relaxing credit constraints. Earlier studies (Ritenberg, 1991, Chhibber and van Wijnbergen, 1992, Uygur, 1993) have also found similar results. Atiyas et al. (1993), on the other hand, report that although financial liberalisation was successful in eliminating exogenous 
constraints created by interest rate controls, credit constraints still operate in the banking sector, basically because of asymmetric information and the agency cost problem. A recent study by Günçavdı and Küçükçifçi (2002) has revealed that despite common neoclassical expectations (Fry, 1989; McKinnon, 1974 and Shaw, 1974), the interdependence between the financial sector and the rest of the economy has drastically weakened, and the financial sector lost its importance, as producing financial service inputs for the production of the other sectors in the post-liberalisation period. Compared with the pre-liberalisation period, productive sectors (such as agriculture, manufacturing and non-financial services) in the economy have begun to demand less financial inputs from the financial sector mainly because of less funds available for their uses and because the cost of uses of financial services is very high. In support of these evidence, CizreSakallığlu and Yeldan (2000) also report that innovations in the increasingly unregulated Turkish financial market helped the public sector in the end meeting its fiscal requirements. Consequently the public sector debt instruments dominated the financial markets and constituted the main source of output growth in the financial sector.

Many research on the Turkish liberalisation policies have mainly investigated changes in the legislative and institutional framework created by the reform programme and their impacts largely on the supply of financial service output. A few studies, so far, have attempted to examine the factors affecting demand for financial service output. Of course, the availability of financial funds is undeniably crucial for economic activities (see Demetriades and Luintel, 2001, Benhabib and Spiegel, 2000, King and Levine, 1993). However any financial reform cannot be regarded as successful unless the availability of funds increased by the reform are used for productive purposes. This paper hence attempts to examine the sources of demand for financial service output and their changing importance in the economy along with economic reforms. In doing so, we introduce a new method of analysis that has not so far been used in the literature to examine the financial sector. This method benefits largely from input-output tables and a useful decomposition of the standard input-output model (see 
Bulmer-Thomas, 1982). ${ }^{1} \quad$ The approach identifies the output and factor use required economy-wide to produce the final output for each destination (e.g. domestic consumption and exports) and from each sector. By giving the central role to inter-sectoral linkages covering entire economy it captures the transmission effects on sources of output.

Following this introductory section, the remainder of the paper is organised as follows. Section II presents a general account of main developments in the Turkish economy and financial policies before and after the financial liberalisation in Turkey. We then present the methodology and the model used in the paper in Section III. Section IV includes empirical results derived from the application of the methodology developed in the previous section. A short summary and concluding remarks are included in Section V.

\section{ECONOMIC BACKROUND AND FINANCIAL REFORMS IN TURKEY}

Turkey began to deregulate her financial markets in 1980 (see Celasun and Rodrik, 1989 and Atiyas and Ersel, 1995). In the period of the pre-deregulation, Turkish financial markets were considered as financially repressed, with different public involvements in the financial markets in the forms of fixing interest rate and exchange rates, heavy tax burden on financial earnings, high liquidity and reserve requirement ratios, preferential credit allocation, limiting the entry to the Turkish financial market etc. (see Fry, 1979). Low and fix interest rates and high inflation, created mainly by expansionary fiscal policies, led to negative real interest rates and discouraged households to deposit their savings in the formal banking sector. The low levels of domestic savings and in turn loanable funds in the banking sector, resulted from fixed interest rates, encouraged Turkish banks to develop a rationing mechanism in allocating loans among alternative demanders in a way of minimising the default risk of their loans. Ambitiously high levels of targeted economic growth rates and insufficiency of domestic savings to finance

\footnotetext{
${ }^{1}$ Input-output methodology was very popular in the 1970s, and partly in the 1980 , to do sectoral analysis investigating structural changes in mostly agriculture and manufacturing sectors, but not for the financial sector. However increasing importance of the financial sector, that is expected to
} 
these rates inevitably resulted in increases in the dependence on foreign savings of the economy. However, particularly in an inhospitable international economic environment of the late 1970s, foreign borrowing of the country became increasingly difficult, causing macroeconomic imbalances. In the period 19791980, Turkey finally experienced severe economic crises, which inevitably paved the way for changing the industrialisation strategy drastically from import substitution to outward orientation.

In January 1980, Turkey undertook a very comprehensive and far-reaching structural adjustment programme. The structural aspect of the programme was first to solve Turkey's internal and external disequilibrium problems, and to reduce the stringency of economic constraints imposed by this disequilibrium (Arıcanlı and Rodrik, 1990; Nas and Odekon, 1992). The initial steps of the programme in this respect involved trade and financial reforms. On the trade side, the determination of foreign exchange rates was liberalised, all quantitative controls on imports, such as quota and licensing system, were removed (Baysan and Blitzer, 1990). Various measures, such as tax rebates and subsidised credit, were implemented to promote export earnings. An improvement in the balance of payments was of great importance to the government in this period to gain creditworthiness that was needed to attract international financial funds from the IMF and the World Bank.

Recognising the role of finance for growth in a financially repressed economy (see Demetriades and Luintel, 2001, Benhabib and Spiegel, 200, King and Levine, 1993), financial liberalisation became very much part of a package of policy reforms, which initially succeeded in restoring growth and significantly increased the openness of the economy. The reform initially aimed at eliminating exogenous financial constraints, which had been created mainly by intensive government interventions and administratively controlled interest rates (see Atiyas and Ersel, 1995, Akyüz, 1990 for detailed survey of the issue). First, interest rates were freed, allowing real interest rates to become positive in the pro-liberalisation period. New financial institutions, such as the Istanbul Stock Exchange and the

constitute a channel between savings (domestic and foreign) and production, in the Turkish economy pays the way for similar research. 
Capital Market Board, were introduced in order to improve the allocation of financial resources through more efficiently operating financial markets, and to reduce the reliance of the corporate sector on internal finance and bank credit. The restriction on the entry into the Turkish financial market by foreign banks was removed, then the number of foreign banks operating in Turkey, as a result, reached 21 compared with 4 in the pre-liberalisation period (Esen, 2000). ${ }^{2}$ An interbank money market was established in 1986. The Central Bank started open market operations first time in 1987. Liberalisation of external capital account finally took place with issuing Decree No. 32 in 1989 (see Ekinci, 2000). With this decree, all controls on capital in- and out-flows were removed, and residences (non-residences) were allowed to buy and sell foreign exchange (TL) and foreign securities (Turkish securities). Turkish commercial banks were allowed to extend foreign currency credit to foreign trade companies. With the application to the IMF for full convertibility of the $T L$, this liberalisation episode was completed in April 1990. The relaxation of capital controls was eventually used by the government to attract international capital to Turkey to finance public sector deficits, rather than private sector projects, and generated a rapid expansion of replacement of the Turkish Lira by to foreign currencies (see Selçuk, 1994). ${ }^{3}$

\footnotetext{
${ }^{2}$ The Turkish private and public banking sectors have gone through a considerable amount of adjustment in the post-liberalisation period. Since one of the aim of the liberalisation was to increase the efficiency and competition in the banking sector, which was dominated mainly by commercial banks. Zaim (1995) evaluated the improvement in the technical and allocative efficiencies (or inefficiencies) of the Turkish banking sector. Regarding inducement in the technical efficiency of the financial liberalisation the banking sector has increased the technical efficiency by 10 percent from 1981 to 1990 . Also differences in technical efficiencies between banks have decreased over time. He reports that technically state-owned banks appear to be more efficient compared to the private banking sector. The gap between the public and private sector banks decreased due to increased competition in the overall banking sector. However the public sector banks show efficiencies because of irrational credit allocation. Another empirical study of Işık and Hassan (2002) covering the period of 19888-1996, indicates that “...cost and profit efficiencies of the Turkish banks are 72 and 83 percent respectively, implying that on average, about 40 percent of the bank resources and about 20 percent of the potential bank profits are wasted during the production of banking services." (Işık and Hassan, 2002, p. 761). The empirical findings of Aydoğan (1993), on the other hand, pointed out that the Turkish banks have market power in the deposit market and financial liberalisation was not successful to achieve a competitive banking sector. Aydoğan's result was supported by the positive effects of inflation and excess demand for loan in the determination of the spread.

${ }^{3}$ Currency substitution became more evident in 1991 with the 7.2 percent share of foreign exchange deposits in GNP from 1.2 percent in 1984. This is particularly important for the government because demand for reserve money establishes a base for seigniorage revenue of the public sector, and exhibits a decreasing pattern over the period between 1984 and 1991. Rodrik
} 


\section{(Table 1 and Figure 1 about here)}

The primary aim of financial reforms was to fill the resource gaps between investment and savings by increasing the availability of financial securities in the economy, and hence to allowed the country to reach high economic growth rates. The overall growth performance of the economy was quite remarkable over the reform period between 1983 and 1993. Following an annual average growth rate of 1.3 per cent per annum over the period of 1977-1980, the economy grew at an average annual rate of nearly 5 per cent until 1994. The share of exports in GDP rose to approximately 8 per cent in 1981-1983 from 3.3 per cent in the period 1977-80, while the share of imports also rose to nearly 14 per cent in the 1981-83 period from 9 per cent in the 1977-1980 period. Table 1 also reveals that foreign trade balance improve in the period of 1984-1988, with 12 percent share of exports in GDP as imports was only16 percent of GDP. However just before the financial crises broke in 1994, trade balance had begun to deteriate and the gap between exports and imports had widened again for the period of 1989-1993. The resource gap between saving and investment, as a share of $G D P$, declined from 5.2 per cent in the $1977-80$ period, first to 1.2 percent in $1981-1983$, and then to 0.6 per cent in 1984-1988 (SPO, 1998).

One sign of the vulnerability of Turkish macroeconomic balances in the pre-reform period was continuously increasing public sector borrowing requirment $(P S B R)$. Fiscal imbalances, measured by the ratio of PSBR to GDP, inreased from 4 percent in early 1980 to 9 percent in the period of 1989-1993, and led the public sector to competing for the financial funds available in the economy with the private sector. Figure 1 shows the amount of financial funds, measured by the ratio of total financial assets available in the economy to $G N P$, which appears to have increased substaintially after 1980 . This can be attributed to financial deepining and output growth in the Turkish financial sector in the prereform period. Figure 1 also indicates that the public sector securities are mainly

(1991) accordingly indicates that $1.5-3$ percent of GNP was generally used to have been financed public sector deficits through revenue from money creation (or seigniorage) and inflation taxes in Turkey. Therefore declines in the demand for reserve money restricted the possible use of seigniorage as a mean of financing fiscal deficits. 
responsible for this dramatic shift in the total amount of financial assets in the market, particularly after 1993.

As far as capital account is concerned, the main feature of the postliberalisation period was a gradual shift in the sources of foreign capital. In the early year of the reform, finance capital was provided largely by multilateral international organisations, such as the World Bank and $I M F,{ }^{4}$ and bilaterial creditors. Begining in 1987, and mostly after the announcement of convertibility of $T L$ in 1989, Turkey eventually found a number of new financing opportunities in international capital markets, and finally in December 1988 entered the Eurodollar market for the first time in several years (see Ersen, 2000). The reliance on private financial funds, since then, has exhibited increasingly crucial roles in credit expansions in the economy in the 1990s.

An important aspect of the financial reforms in the 1980s was to increase the availability of financial funds and accordingly to design institutional environment. As stated above, the Turkish financial liberalisation throughout the 1980s, to some extent, reduced the strincency of financial constraints on economic activities, and increased the availability of funds. However the use of these funds have been influenced by other macroeconomic developments, most importantly by public sector behaviour, in the economy. In order to assess whether the Turkish financial reform has had sustainably positive contributions to entire economic growrth of the country, it is necessary to examine the sources of output growth. Changing role of the financial services, as an intermediate input, in the production of other sector can constitutes a good indication regarding how important each sector is for the economy. These changes in growth can then be attributed to the following factors:

The first factor for output gains and/or losses can be considered as import penetration in the Turkish economy after the trade and financial reforms. Trade reforms ease the flow of goods while capital account liberalisation allows residences, as well as non-residences, to transfer capital across borders freely.

\footnotetext{
${ }^{4}$ Between 1980 and 1984, the World Bank granted Turkey five one-year structural adjustment loans (SALs), amounting \$1.6 billion. They were all used in supporting policy reforms proposed by the adjustment programme (see Kirkpatrick and Öniş, 1991).
} 
Increased import competition in a particular sector after trade and capital account liberalisation, for example, causes the domestic production to loss market share with a decline in its output level.

The contracting-out effect can be considered as the second reform-related causes for changing in output growth. Deregulation in markets, along with other measures of reforms, increases the weights of the market mechanism for the efficient allocations of economic resources. Deregulation in financial markets, for example, is expected to encourage firms to rely increasingly on specialised suppliers, such as banks and equity market, instead of producing their own financial. This contracting-out behaviour, of course, creates extra demand for the production of other sectors and positively contributes to the overall economic growth of the country. Financial development achieved by liberalisation in this sense is expected to make the other sectors to obtain financial inputs easily, and to create even more demand for financial sector output. Financial innovations that financial liberalisation brings about can be considered as a stimuli to create additional demand for sectoral financial output.

Import substitution in final and intermediate good demand (indicating a rise in the home share in the demand for final and intermediate goods) could be another source for output gains, and can be named here as the import-substitution effect. Capital account liberalisation, for example, could lead to import penetration by foreign financial organisations and hence to a drop in financial output.

In the following section we present an empirical framework to show these compositional structural changes in output growth in the financial sector.

\section{METHODOLOGY}

In this section we introduce the accounting approach to the analysis of patterns of economic growth pioneered by Chenery et al. (1962) using input-output framework (also see Gregory et al., 2001; Albala-Bertrand, 1999; Schumann, 1990 and Chenery et al., 1986). We then apply this framework to the Turkish input-output tables in order to investigate the source of economic growth in the financial sector. Input-output models are based on some restrictive assumptions 
of fixed input-output coefficients with constant returns to scale, fixed factor shares in production and perfectly elastic supplies of factors of production (see BulmerThomas, 1982). The Leontief production function is often criticised for its assumption of fixed coefficients in input use. Since we utilise input-output tables observed at two separate dates we obtain direct measures of the change in input use over time. Therefore, the only necessary assumption on the production function is constant returns to scale across all inputs at each point in time. In a standard input-output framework the flows of all goods in an economy with $n$ industries can be written as follows:

$$
\mathbf{x}=(\mathbf{I}-\mathbf{A})^{-1}(\mathbf{f}+\mathbf{e})
$$

where $\mathbf{I}$ and $\mathbf{A}$ respectively are the unit matrix and the matrix of input-output coefficients, whose element $a_{i j}$ represents the unit-input requirement of the $j^{\text {th }}$ industry for the output of the $i^{\text {th }}$ industry, all with $(n \times n)$ dimension. $\mathbf{x}$ is the column vector of sectoral production, with $(n \times 1)$ dimension. $\mathbf{f}$ and $\mathbf{e}$, respectively, are the vectors of total final demand and exports, both with $(n \times 1)$ dimension.

The balance equation for the flow of domestic output can be written as follows:

$$
\mathbf{x}=\mathbf{w}^{\mathbf{d}}+\mathbf{f}^{d}+\mathbf{e}
$$

where $\mathbf{f}^{\mathrm{d}}$ : the vector of flows of domestic final use; $\mathbf{w}^{\mathrm{d}}$ : the vector of flows to domestic intermediate use, which is given by:

$$
\mathbf{w}^{\mathbf{d}}=\mathbf{A}^{\mathbf{d}} \mathbf{x}
$$

Upon substituting (3) into (2),

$$
\mathbf{x}=\mathbf{A}^{\mathbf{d}} \mathbf{x}+\mathbf{f}^{d}+\mathbf{e}
$$

Imports are included in this framework by assuming that imported goods for intermediate and final uses are in fixed proportion of total. In other words,

$$
\mathbf{A}^{d}=\mathbf{h} \mathbf{A} \text { and } \mathbf{f}^{d}=\mathbf{s f}
$$


where A: the matrix of input-output coefficients, h: domestic supply ratio in intermediate uses, $\mathbf{s}$ : domestic supply ratio in final uses. Substituting (4) into (3) renders the following:

$$
\mathbf{x}=\mathbf{h A x}+\mathbf{s f}+\mathbf{e}
$$

Solving (6) with respect to $\mathbf{x}$ gives

$$
\mathbf{x}=(\mathbf{I}-\mathbf{h} \mathbf{A})^{-1}(\mathbf{s f}+\mathbf{e})
$$

This relationship holds for any point in time, and differencing it with respect to time and rearranging the resulting expression give us the change in gross output between any two periods of time. This final expression allows us explicitly to see the sources of these changes in gross output as follows:

$$
\Delta \mathbf{x}=\mathbf{R} \Delta \mathbf{s f}+\mathbf{R s} \Delta \mathbf{f}+\mathbf{R} \Delta \mathbf{e}+\mathbf{R} \Delta \mathbf{h} \mathbf{A x}+\mathbf{R h} \Delta \mathbf{A x}
$$

where $\Delta$ denotes the change over time; $\mathbf{R}=(\mathbf{I}-\mathbf{h} \mathbf{A})^{-1}$ is the Leontief inverse matrix. The level terms in equation (5) can be evaluated as beginning and end values, which are similar to Paasche and Laspeyres index weighting. The derivation of the formula for either use is analogous (see Günçavdı and Küçükçifçi, 2001), and yields the following two results for Paasche and Laspeyres index weighting respectively: ${ }^{5}$

$$
\begin{aligned}
& \Delta \mathbf{x}=\mathbf{R}_{1} \Delta \mathbf{s f}_{0}+\mathbf{R}_{1} \mathbf{s}_{1} \Delta \mathbf{f}+\mathbf{R}_{1} \Delta \mathbf{e}+\mathbf{R}_{1} \Delta \mathbf{h} \mathbf{A}_{0} \mathbf{x}_{0}+\mathbf{R}_{1} \mathbf{h}_{0} \Delta \mathbf{A} \mathbf{x}_{0} \\
& \Delta \mathbf{x}=\mathbf{R}_{0} \Delta \mathbf{s f}_{1}+\mathbf{R}_{0} \mathbf{s}_{0} \Delta \mathbf{f}+\mathbf{R}_{0} \Delta \mathbf{e}+\mathbf{R}_{0} \Delta \mathbf{h} \mathbf{A}_{1} \mathbf{x}_{1}+\mathbf{R}_{0} \mathbf{h}_{0} \Delta \mathbf{A} \mathbf{x}_{1}
\end{aligned}
$$

where the subscript 0 and 1 represent the initial and terminal years respectively. Equation (9) allocates the change in gross output among changes in the various components of its use: the changes in domestic final demand $(\Delta \mathbf{f})$; the changes in exports $(\Delta \mathbf{e})$; the changes in the home shares in final consumption (import substitution in final demand) $(\Delta \mathbf{s})$; and the changes in the home shares in intermediate goods (import substitution in intermediate goods) $(\Delta \mathbf{h})$. The term $\Delta \mathbf{A}$ explicitly allows the input-use coefficients to vary over time in a way that will be determined by the data.. These changes in Leontief coefficients are interpreted as

\footnotetext{
${ }^{5}$ The formal derivation in detail is available in Appendix A.
} 
technical changes in the production. In what follows, equation (9) is then applied to the data of the Turkish economy.

\section{EVALUATING THE EMPIRICAL RESULTS}

The aim of this section is to examine the macroeconomic sources of changes in the production of the financial sector ${ }^{6}$ before and after the liberalisation of financial markets, and to relate the changes in the sources of financial output productions to macroeconomic policies. Our main expectations regarding the impacts of financial reforms are to see upon the availability of financial funds in the economy. We expect that the financial reform increases the funds available for the use of other sectors and stimulates the production of the financial sectors in the economy. According to neoclassical expectation, increases in the availability of financial funds relax the stringency of financial constraints in the supply side of the economy and contribute the overall growth performance of the economy positively.

We employ mainly four available input-output tables, which reflect the different structures of the Turkish economy before and after the financial reforms. The first table is for 1973, a period of the pre-liberalisation. The second one is for 1985 , which is used to examine the immediate impacts of early liberalisation episode. The third one is the table for 1990, which is the first table after the implementation of convertibility of Turkish Lira. Finally the last one has recently published for 1996, which can be used to examine the effects of capital account liberalisation. Although another table is available for the pre-liberalisation period for 1979 , the results based on this table lacks credibility because this year was a year of foreign exchange shortage, which caused various constraints on the supply side of the economy (e.g. see Bilginsoy, 1993).

An investigate influences of financial reforms on the sources of output in the financial sectors requires an intertemporal comparisons of the sources of

\footnotetext{
${ }^{6}$ In the formal input-output tables of Turkey, there is only one entity regarding the financial sector, which compromise banking and insurance sector. However the importance of insurance sector in the Turkish economy is very small, the figure for this entity can be interpreted as reflecting mainly production relationship of the banking sector with the rest of the economy. From now on, this sector is named as the financial sector.
} 
outputs in the Turkish economy. This comparison however necessitates handling changes in price levels, particularly in a highly inflationary country such as Turkey. The price adjustment procedure is introduced in Appendix B just to keep the discussions in this section as simple as possible (see also Günlük-Şenesen and Küçükçifçi, 1994). The first three input-output tables include 64 sub-sectors while the recent one contains 97 sectors. Nevertheless we must first aggregate them to 24 sub-sectors because price indices, which are required to produce the real values, are only available at this aggregation level. However, we further reduce the number of sectors to 5 merely to see the influence of reforms on the economy clearly. ${ }^{7}$ These main sectors are namely agriculture, mining, manufacturing, nonfinancial services and financial services. The price indices for manufacturing are wholesale price indices for services compiled from the Sate Institute of Statistics $(S I S)$ for 1990. The price indices for services are implicit GNP deflator computed from SIS data. All index values are, however, adjusted to the based year 1973 for our purpose. ${ }^{8}$

\section{Results}

\section{Overall Economy}

Table 2 shows the total and sectoral growth rates and the shares of sectoral outputs. Over the 24 year of period between 1973 and 1996, the economy seems to grow almost 324 percent with, on average, about 7 percent growth rate per annum. ${ }^{9}$ The striking feature of the growth rates over the sub-periods is that the economy grew more rapid per annum in the period of 1985-1990 than other

\footnotetext{
${ }^{7}$ Aggregation for 24 sectors are presented in Appendix C.

${ }^{8}$ According to the State Institute of Statistics (SIS), the price level for the financial sector for a certain year is derived through dividing the nominal value of the sectoral output level for this particular year by the nominal value of the sectoral output calculated for a given base year. The SIS, however, is not able to measure the value of the sectoral output in the Turkish financial sector directly. Instead, it relies, in the calculation, on a very restrictive assumption that the financial sector output grows at the same rate as employment (SIS, 1994). This method, naturally, arises some concerns. The method ignores the effects on output growth of labour-saving technical improvement. In particular the finance sector has achieved continuously to increase technological efficiency, which has brought about reductions in employment (or no change). In such cases where employment is stagnant or decreasing after output technological improvement, the sectoral output level will wrongly calculated as stagnant or decreasing according the method used by the SIS. However, despite this defect, the output level calculated by the SIS is the only available data for the financial sector in Turkey.

${ }^{9}$ Annual growth rates are calculated as geometric average of each corresponding period.
} 
periods. In the period of 1973-1985 covering the initial episode of structural adjustment, this rate is 6 percent while it is only 5 percent in the period of capital account liberalisation.

The financial sector, on the other hand, appear to have performed very well in the first sub- period of 1973-1985 with almost 5 percent average output growth rate per annum. However, this performance seems eventually to have diminished in the following two periods and reached around 2.5 percent. Although it plays an important role in the formation of current crises, the share of the financial sector output level noticeably very small, and this share appeared to have declined over time.

\section{(Table 2 about here)}

To assess the reason behind these changes in the gross output growth we examine the determinants of total and sectoral output growth by applying equation (9) to the Turkish data. The results based on two different weighting are reported in Table $3 \mathrm{a}$ and Table $3 \mathrm{~b}$. Each table consists of four different panels, which present the sources of output growths in five main sectors as well as the overall economy. Among them, the first panel includes overall changes in the output growth from 1973 to 1996 , which help us assessing the change in the engines of output growth over a whole period. The second one is reported to show the effects of financial reforms in the early 1980s. The effects of external account liberalisation and expansion in the volume of domestic credit on the financial as well as other sectors can be seen in the third and fourth panels. Another important observation from these tables is that although the calculated values are different, the chose of different weighting does not cause any changes in our qualitative interpretations.

\section{(Table $3 a$ and Table $3 b$ about here)}

The figures in Table $3 \mathrm{a}$ are the percentage shares of each source in the total output growth. In an overall assessment of the whole period of 1973-1996, final demand ${ }^{10}$ appears to be accounted for almost 79 percent of total changes in aggregate output, while another demand component, exports, explains nearly 20 
percent of total output growth. Import substitution in final demand is responsible only for the 2 percent of total changes in output, as import penetration in intermediate goods causes only a 1 percent reduction. With these figures, it seems that the great extent of changes in total output growth is originated from final domestic demand and exports in the Turkish economy. Surprisingly, change in technology, which one expects to happen in such a long period, provides only 0.1 percent of total output growth in Turkey.

In the first sub-period of 1973-1985 final demand appears to be the leading source of the output growth with the almost 77 percent shares. When another component of final demand, exports, was considered, the final demand explains 91 percent of total changes in output over the period of 1973-1985. It is also clear in the table that contribution of export demand to overall output growth in this period is 24 percent, which was the highest value that the Turkish economy had performed so far. This high performance of exports was achieved mainly through export promotion policies in the early 1980s. One crucial factor that could be regarded as important as incentive structure, created by these polices, was the presence of under-utilised-production capacity that had been created in he 1970s, but had not been used because of foreign exchange shortages (see Bilginsoy, 1993).

The share of import substitution in final demand appears to be very limited, but positive with 1.3 percent in total output growth. The figure in Table (3a) importantly shows that the pace of import substitution in intermediate goods seems to be very slow, which resulted in 0.6 percent reduction in output growth. This finding is, however, not surprising because trade liberalisation is expected to encourage imports of intermediate goods rather than producing them domestically in the early liberalisation period.

Technological changes in the production structure of the economy that appeared to happen over the period of 1973-1985 were against the domestic production. From the figures in the table, technological changes reduced overall growth rates by 1.7 percent. This result can also be read as domestic economy had eventually increased its dependence level of production on foreign goods.

${ }^{10}$ Final demand here includes domestic consumption, investment and government expenditure. 
The period of 1985-1990 was marked with capital account liberalisation and huge capital inflow to Turkey. While final demand continued to be the main leading stimuli for output growth exports lost its earlier pace in this period. This slowdown drastically reduced the contribution of exports from 24 percent in the earlier period to 3 percent in the 1985-1990 period. However, import substitution in final demand accelerated in this period and became responsible for the 10 percent of overall output growth. This is clear evidence that imported final goods had been replaced by domestic production. On the other hand the economy continued to import intermediate goods which accounted for 3.1 percent decline in growth. Changes in technology of production seem to have shifted toward the one requiring more domestically produced goods, which explains almost 13 percent of output growth in the period.

In the 1990-1996 period final demand and exports explain more than 100 percent of gross output growth. Surprisingly exports possess the highest influence on output growth, with 32 percent, in this period when export promotion policies have central importance and $T L$ overvalued time to time. As import substitution lost its pace compared with the earlier period, output loss created by changes in technology became responsible for almost 15 percent decline in gross output growth.

In sum, final demand and exports generally appear to be two leading forces behind output growth in the Turkish economy. Import substitution seems not to have been crucial factors in period of time in Turkey, particularly in the period of 1973-1985 in which the import substitution industrialisation strategy was considered as the engine of output growth until 1980.

\section{Financial Sector}

Decomposition of the changes (Table $3 \mathrm{a}$ and $3 \mathrm{~b}$ ) reveals that over the whole period, rising domestic final demand, exports and rising home share in the final demand (i.e. import substitution in final demand) were positive influences for output growth, and import penetration in intermediate goods and changing Leontief coefficients were negative influence in the financial sector. Final demand made the largest contribution to the growth of gross output in the 
financial service with the share of more than 100 percent. Exports boom seems to have the second important positive contribution to financial output growth with almost 24 percent. The extra output generated by rising home share in final demand, on the other hand, was broadly cancelled out by the loss of import penetration in intermediate goods. In particular import substitution in final demand explains only 2 percent of output growth as import penetration in intermediate goods appears to be responsible only 1.3 percent decline in output growth. Interestingly technological changes measured by changes in Leontief coefficients in this period accounted for 41 percent decline in total output growth. High cost of borrowing and instability in financial markets in the postliberalisation period can be considered as the discouraging factors for the other sector demanding financial sector output.

There are some sharp differences between the periods underlined by different economic policies. When we examine the entire period closely, the period of 1973-1985 includes the influence of the early episode of liberalisation, in which deregulation in financial markets along with other commodity markets and trade reforms took place. During the period of 1981-1983 for example, inflation was moderately high with almost 57 percent rate, despite a mild drop from 62 percent in the earlier period of 1977-80. Real exchange rate depreciated almost 12 percent in the same period, which must have influenced the domestic productions negatively, particularly, in the sectors with high imported input dependence. Liberalisation efforts together with real depreciation of Turkish Lira also influenced the export performance of the country with almost 8 percent of GDP in the period of 1981-1983, while imports share in GDP jumped from about 9 percent in the period of 1977-1980 to 14 percent. Real interest rates as a simple indication of cost of financial services, were positive and very high in the postliberalisation period.

During the first sub-period of 1973-1985, almost 93 percent of sectoral output growth in the financial sector is provided by the final demand while approximately 33 percent arose from export booms which took place in the first years of the liberalisation period. Despite the sharp increase in the share of aggregate imports in GDP, the share of home goods in final demand appears to 
have slightly increased financial sector output by 1.5 percent, while import penetration in intermediate goods declined only 1 percent. This stands out as the fact that rising imports in this period has caused, albeit general expectations, no output losses and deindustrialisation in the financial sector. Results in the table reveal the role of inter-industry demands for financial services. Despite the introduction of new and expending financial services in the early liberalisation period, inter-industry demand for financial services seems to have decreased by almost 26 percent, as other sectors lowered the financing and insurance components of their products.

The second sub-period of 1985-1990 was marked by capital account liberalisation and policy reversals in some reforms (see Yentürk, 2002 and Yentürk and Ülengin, 2001). The most striking feature of this period is the output growth rate of the finance sector, 12.5 percent, which appears to be the lowest compared with other periods. While inflation soared about 50 percent, domestic currency lost its competitive position and started being over valued. Table 1 shows that domestic currency overvalued by 0.67 percent in the period of 19841988 and 6.45 percent in the period of 1989-93. As an immediate effect of this movement in the value of $T L$, the share of exports in GDP declined from almost 12 percent in the 1984-88 period to 9 percent in the period of 1989-93. Together with the decline in total exports in the economy, the contribution of export demand to the sectoral output growth became negative with the 14 percent share. The most striking feature of the period is that output gains by final demand in the financial sector, 295 percent, were dramatically cancelled out by the loss of changing Leontief coefficients, which was almost -198 percent. Some of the decline in the growth of demand for financial services undoubtedly reflects that firms in other sectors met their demand for financial services within firm, ${ }^{11}$ and eventually became less and less independent from the service provided by the

\footnotetext{
${ }^{11}$ Trade credits in this and the following periods were an important source of finance of the Turkish firms. Using a large data set of the Central Bank of Turkey, Özatay et al (1996) states that the rate of trade credit in total debt of a typical firm is 29 percent in 1991, 31 percent in 1992 and 33 percent in 1993. In a smaller data set, which includes firms registrated in Istanbul Stock Exchange, the ratio of short-term trade credit to total liabilities is 12 percent for the period of 1989-96 (Günçavdı et al, 1999). This research also shows that the 50 percent of total liabilities of the firms in the stock exchange was financed through internal finanacial sources in the same period.
} 
financial sector. In particular Ersel and Öztürk (1993) enlighten this feature of the Turkish corporate sector, and noted a noticeable decline in the share of bank loans in the post liberalisation period. One reason for this might have mainly been high and volatile interest rates in the post-liberalisation period. Increase public sector demand for financial funds to finance the public deficits increased drastically in this period. While, the ratio of public sector borrowing requirement to GDP in the period of 1984-88 was about 5 percent, this ratio rose almost 80 percent and reached 9 percent of GDP in the period of 1989-93. As this drastic change in the demand for financial funds crowed out the private sector from the demand pool of loans from the financial sector through restricting the availability of financial funds for the use of the private sector, it also put increasing pressure on the cost of borrowing from the formal financial market.

Rising home share in final demand appears to have accounted for 23 percent of the output growth. Import penetration in intermediate goods was, on the other hand, still negative and around 7 percent.

The share of sectoral output in total in 1996 appear to decline to 1,19 percent from 1.4 percent in 1990. The sector grew from 1990 to 1993 almost by 17 percent which was still less than that of the early liberalisation period. Estimates in the table show that almost 150 percent of this negligible growth rate in financial service output was accounted for final demand. During this period when the $T L$ was substantially below its fundamental equilibrium exchange rate for the most of this time period (see Table 1), export booms created an extra demand for financial services by the amount of 62 percent, and import substitution in final demand led to 2.5 percent of total financial sector output growth.

Empirical results imply that final demand and exports particularly in the last period seem to be two crucial deriving factors that provides financial output growth in the banking and insurance sector. However, their positive effects are mostly largely counterbalanced by the impact of decreasing financial service inputs requirements per unit of gross output of the other sectors. This clearly indicates that the use of financial output as input increasingly becomes negligible 
in the domestic production. This however contradicts with the general expectation from the financial reform.

\section{CONCLUSION}

Turkey undertook a large scale structural adjustment programme with financial reforms as an integral part in the 1980s. Empirical results show that the economy responded to these reforms very well and the total output in the economy increased more than 100 percent from 1973 to 1985. Financial reforms also worked to increase the out put level of the financial sector by 75 percent, the highest amongst those rates of the other sub-periods after the liberalisation. However, the output growth rates of the finance sector later on dropped drastically, and never reached its earlier levels. The paper puts forward that changes in macroeconomic policies and instability of the economy created mainly by high public involvements into financial markets. Restricting the availability of loanable funds by high public demand for funds and high and instable interest rates appear to have crowed out the private sector from the formal financial markets.

Despite undistinguished growth performance of the financial sector in the post-liberalisation period, final demand became to be accounted for the majority of output growth. However, it is also evident from changing Leontief coefficients (whish is named as technological changes) that there were genuine declines in intermediate demands of the other sectors for services from banks and insurance companies, as they decreased the financing service components of their production. This postulates that the Turkish corporate sector increasingly became independent from the use of the output produced by the financial sector and eventually relied upon other sources of financing such as internal finance and/or trade credits. Additionally this pattern became more evident in the period after the capital account liberalisation.

In conclusion, the reforms in financial markets helped the economy grown rapidly in the early period of liberalisation, but the financial sector seems not to have contributed to the overall growth rate of the economy in the later periods. 
Final demand and exports demand come out as an important factors contributing to the output growth of the sector. Besides, creating strong and stable financial markets, which can encourage the other sectors to increase financial service components of their production, seem to increase the output growth of the financial sector.

\section{REFERENCES}

Akyüz, Y. and K. Boratav (2002), "The Making of the Turkish Financial Crisis”, University of Ankara, mimeo. Available on line at (www.bagimsizsosyalbilimciler.org/yazilar/AkyuzBoratav.htm).

Akyüz, Y. (1990),'Financial System and Policies in Turkey in the 1980s", Political Economy of Turkey: Debt, Adjustment and Sustainability in T. Arıcanlı and D. Rodrik (der.), s. 98-131, (New York: MacMillan).

Albala-Bertrand, J.M. (1999), "Structural Changes in Chile: 1960-1990", Economic System Research 11 (3): 301-319.

Arıcanlı, T. and D. Rodrik (1990), The Political Economy of Turkey: Debt, Adjustment and Sustainability, (London: MacMillan Press).

Atiyas, I. and H. Ersel (1995), “The Impacts of Financial Reforms: The Turkish Experience”,, in Financial Reform: Theory and Evidence, G. Caprio, I. Atiyas and J. Hansson (eds.), (New York: Cambridge University Press).

Atiyas, I., H. Ersel and E. Öztürk (1993), "Customer Pattern and Credit rationing in Turkish Banks", Research Department Discussion Papers No. 9301, (Ankara: Central Bank of Turkey).

Aydoğan, K. (1993), “The Competitive Structure of the Turkish Banking Sector”, in Y. Aşıkoğlu and H. Ersel (eds.), Financial Liberalisation in Turkey, pp. 167-180, (Ankara: central Bank of Turkey).

Benhabib, J. and M.M. Spiegel (2000), "The Role of Financial Development in Growth and Investment", Journal of Economic Growth 5: 341-360.

Bilginsoy, C. (1993), "Inflation, growth, and import bottlenecks in the Turkish manufacturing industry", Journal of Development Economics 42: 111-131.

Bulmer-Thomas, V. (1982), Input-Output Analysis in Developing Countries, (New York: Wiley).

Chenery, H., S. Rabinson, and M. Syrquin (1986), Industrialisation and Growth: A Comparative Study, (Oxford and New York: World Bank and Oxford University Press).

Chenery, H., S. Shishido and T. Watanabe (1962), "The Pattern of Japanese Growth 1914-54", Econometrica 30 (1): 98-131.

Celasun, M. and D. Rodrik (1989), "Debt, Adjustment and Growth: Turkey", in J.D. Sach and S.M. Collins (eds.), Developing County Debt and economic Performance: Country StudiesIndonesia, Korea, Philippines, Turkey, (Chicago; University of Chicago Press).

Chhibber, A and S. van Wijnbergen (1992), "Public Policy and Private Investment in Turkey", in A. Chhibber, M. Dailami, and N. Shafik (eds.), Reviving Private Investment in Developing Countries, (Amsterdam: North-Holland).

Cizre-Sakallığlu, Ü. And E. Yeldan (2000), "Politics, Society and Financial Liberalisation: Turkey in the 1990s", Development and Change 31 (2): 481-508.

Demetriades, P. O. and K.B. Luintel (2001), "Financial Restraints in the South Korean Miracle", Journal of Development Economics 64: 459-479.

Ekinci, N. K. (1998), “The Dynamics and Adjustment of Economic Crises in the Post-1980 period in Turkey", Toplum ve Bilim (Society and Science), 77. (in Turkish)

Ersel, H. and E. Öztürk (1993), "Liberalisation Attempts and the Financial Structure of Turkish Corporations", in Financial Liberalisation in Turkey, Y. Aşıkoğlu and H. Ersel (eds.), Central Bank of Turkey, Ankara.

Esen, O. (2000), "Financial Openness in Turkey", International Review of Applied Economics 14 
(1), pp. 5-23.

Fry, M. (1988), Money, Interest and Banking in Economic Development, (Baltimore: John Hopkins University Press).

Fry, M. (1979), "The Cost of Financial Repression in Turkey", Saving and Development no. 2: 127-135.

Günçavd1, Ö., H. Levent and M. Bolak (1999), Determinants of Financial Structure of Manufacturing Firms in the Istanbul Stock Exchange, Turkish Bank Association, Publication No. 209. (in Turkish)

Günçavd1, Ö., M. Bleaney ve A. McKay (1999), "Private Investment and Structural Adjustment A Case Study of Turkey”, Journal of International Development, 11: 221-239.

Günçavd1, Ö., M. Bleaney and A. McKay (1998), "Financial Liberalisation and Private Investment: Evidence from Turkey", Journal of Development Economics, 57: 443-455.

Günçavd1, Ö. and S. Küçükçifçi (2002), "An Assessment on the Performance of Financial Liberalisation and Financial Markets in Turkey", Forthcoming in METU Studies in Development (in Turkish).

Günlük-Şenesen, G. and S. Küçükçifçi (1994), "Decomposition of Structural Change into Technology and Price Components: Turkey, 1973/1985”, Economic Systems Research 6 (2): 199-215.

Gregory, M., B. Zissimos and C. Greenhalgh (2001), “Jobs for the Skilled: How Technology, Trade, and Domestic Demand Changed the Structure of UK Employment, 1979-990", Oxford Economic Papers 53: 20-46.

King, R. and R. Levine (1993), "Finance, Enterpreneurship and Growth: Theory and Evidence", Journal of Monetary Economics 32 (3): 513-542.

Kirkpatrick, C. and Z. Öniş, (1991), "Turkey”, in P. Mosley and J. Harrigan, and J. Toye (eds.), Aid and Power: The World Bank and Policy-Based Lending, Vol. 2, Case Studies (London: Routledge).

Işık, I and M.K. Hassan (2002), “Technical, Scale and Allocative Efficiencies of Turkish Banking Industry", Journal of Banking \& Finance 26: 719-766.

Martin, J. and J. Evans (1981), "Notes on Measuring the Employment Displacement Effects of Trade by the Accounting Procedure", Oxford Economic Papers 33 (1): 154-164.

McKinnon, R.I. (1974), Money and Capital in Economic Development, (Washington: Brooking Institution).

Nas, T. and M. Odekon (1992), Economics and Politics of Turkish Liberalisation, (Bethlehem: Lehigh University Press).

Rodrik, D. (1991), "Premature Liberalisation, Incomplete Stabilisation: The Özal Decade in Turkey”, in M. Bruno, S. Fischer, E. Helpman, and N. Liviatan with L.R. Meridor (eds.), Lessons of Economic Stabilisation and Its Aftermath, (Cambridge, M.A.: The MIT).

Rittenberg, L. (1991), "Investment Spending and Interest Rate Policy: the Case of Financial Liberalisation in Turkey", Journal of Development Studies 27 (2): 151-167.

Özatay, F (2000) "A Quarterly Macroeconometric Model for a Highly İnflationary and Indebted Country: Turkey", Economic Modelling 17: 1-11.

Özatay, F., E. Öztürk, and G. Sak (1996), Problems of the Turkish Corporate Sector and Alternative Sources of Finance, TUSIYAD, Publication No. TUSIYAD-T/96-1/192, Istanbul. (in Turkish).

Schumann, J. (1990), “On Some Basic Issues of Input-Output Economics: Technical Structure, Prices, Imputations, Structural Decomposition, Applied General Equilibrium”, Economic System Research 2 (3): 229-239.

Selçuk, F. (1994), "Currency Substitution in Turkey", Applied Economics 26: 509-518.

Shaw, E. (1974), Financing Deepening in Economic Development, (New York: Oxford University Press).

State Institute of Statistics (1994), Gross National Product: Concepts, Methods and Sources, (Ankara: SIS), (in Turkish).

State Planning Organization (1998), Economic and Social Indicators (1950-1997), Ankara: SPO.

Uygur, E. (2001), "Turkey from Crisis to Crisis: November 2000 and February 2001 Crises", Turkish Economic Institution Discussion Paper, No. 2001/1. (in Turkish)

Uygur, E. (1993), Financial Liberalisation and Economic Performance in Turkey, (Ankara: Central Bank). 
Yeldan, E. (2001), “On the IMF-Directed Disinflation Programme in Turkey: a Program for Stabilisation and Austerity or a Recipe for Impoverishment and Financial Chaos?", Bilkent University Department of Economics, mimeo..

Yentürk, N. (2002), "Last 20 Years of the Turkish Economy", İstanbul Technical University, Department of Management, mimeo..

Yentürk, N. and B. Ülengin (2001), "Impacts of Capital Inflows on Aggregate Spending Categories: the Case of Turkey", Applied Economics 33: 1321-1328.

Zaim, O. (1995), "The Effect of Financial Liberalisation on the Efficiency of Turkish Commercial Banks", Applied Financial Economics 5: 257-264.

\section{Appendix A: Derivation of Equation (9) in Detail}

We start the formal derivation from equation (7)

$$
\mathbf{x}=(\mathbf{I}-\mathbf{h} \mathbf{A})^{-1}(\mathbf{s} \mathbf{f}+\mathbf{e})
$$

For simplicity and tractability, let $\mathbf{D}=(\mathbf{I}-\mathbf{h} \mathbf{A})$ and $\mathbf{g}=(\mathbf{s} \mathbf{f}+\mathbf{e})$, and write equation (B-1) as follows:

$$
\mathbf{x}=\mathbf{D}^{-1} \mathbf{g}
$$

Equation (B-2) holds for any point in time with $\mathbf{x}, \mathbf{A}, \mathbf{f}, \mathbf{e}, \mathbf{h}$ and $\mathbf{s}$. Then differencing (B-2) yields

$$
\Delta \mathbf{x}=\mathbf{x}_{\mathbf{1}}-\mathbf{x}_{0}=\Delta\left(\mathbf{D}^{-\mathbf{1}} \mathbf{g}\right)=\left(\mathbf{D}_{1}^{-1} \mathbf{g}_{1}\right)-\left(\mathbf{D}_{0}^{-1} \mathbf{g}_{0}\right)
$$

Equation (B-3) can be expressed in a way that each terms on the right-hand side of the equation increase by the amounts of $\Delta \mathbf{D}^{-1}$ and $\Delta \mathbf{g}$ respectively between time 0 to time 1 . We then obtain

$$
\Delta \mathbf{x}=\left(\mathbf{D}_{0}^{-1}+\Delta \mathbf{D}^{-1}\right)\left(\mathbf{g}_{0}+\Delta \mathbf{g}\right)-\mathbf{D}_{0}^{-1} \mathbf{g}_{0}
$$

Upon expanding (B-4), we get

$$
\Delta \mathbf{x}=\mathbf{D}_{0}^{-1} \mathbf{g}_{0}+\mathbf{D}_{0}^{-1} \Delta \mathbf{g}+\Delta \mathbf{D}^{-1} \mathbf{g}_{0}+\Delta \mathbf{D}^{-1} \Delta \mathbf{g}-\mathbf{D}_{0}^{-1} \mathbf{g}_{0}
$$

Cancelling out the similar terms, we finally derive the following expression:

$$
\Delta \mathbf{x}=\mathbf{D}_{0}^{-1} \Delta \mathbf{g}+\Delta \mathbf{D}^{-1} \mathbf{g}_{0}+\Delta \mathbf{D}^{-1} \Delta \mathbf{g}
$$

In calculating equation (B-6), it is quite important the way we handle the last interactive term (see Martin and Evens, 1981). Some similar studies in the literature recognise the presence of the last term, but none explicitly calculate it, preferring instead to calculate it as a residual. However, we here follow a different way. In the present context, we assume that either the first or the second tem on the right hand side of (B-6) can compromise this last term. If the first term includes the 
last term, then equation (B-6) become weighted by the terminal year of the structural $\mathbf{D}^{-1}$ and the base year of the volume $\mathbf{g}$, and vice versa if the this term is absorbed by the second one. This is rather similar to Paasche and Laspeyres index weightings respectively. Given this explanation, equation (B-6) respectively can be re-written as follows:

$$
\begin{aligned}
& \Delta \mathbf{x}=\mathbf{D}_{1}^{-1} \Delta \mathbf{g}+\Delta \mathbf{D}^{-1} \mathbf{g}_{0} \\
& \Delta \mathbf{x}=\mathbf{D}_{0}^{-1} \Delta \mathbf{g}+\Delta \mathbf{D}^{-1} \mathbf{g}_{1}
\end{aligned}
$$

Despite the fact that the calculations using both weighting yield the analogous, we use the Laspeyres weighting for presentation. However, the same derivation can be repeated for the Paasche weighting. For the our present purpose, the first term on the right-hand side of (B-8) can be decomposed as follows:

$$
\mathbf{D}_{0}^{-1} \Delta \mathbf{g}=\mathbf{D}_{0}^{-1}\left[\left(\mathbf{s}_{1} \mathbf{f}_{1}+\mathbf{e}_{1}\right)-\left(\mathbf{s}_{0} \mathbf{f}_{0}+\mathbf{e}_{0}\right)\right]
$$

Adding and subtracting the term $\mathbf{s}_{0} \mathbf{f}_{1}$ from the right-hand side of (B-9) yields:

$$
\mathbf{D}_{0}^{-1} \Delta \mathbf{g}=\mathbf{D}_{0}^{-1}\left(\Delta \mathbf{s f}_{1}+\mathbf{s}_{0} \Delta \mathbf{f}+\Delta \mathbf{e}\right)
$$

The second-term on the right-hand side of (B-8), on the other hand, can be decomposed as:

$$
\Delta \mathbf{D}^{-1} \mathbf{g}_{1}=\left(\mathbf{D}_{1}^{-1}-\mathbf{D}_{0}^{-1}\right) \mathbf{g}_{1}
$$

Since multiplying the first and the second term in the bracket on the right-hand side of (B-11) by $\left(\mathbf{D}_{0}{ }^{-1} \mathbf{D}_{0}\right)$ and $\left(\mathbf{D}_{1} \mathbf{D}_{1}{ }^{-1}\right)$ does not change equation (B-11), the following can also be written:

$$
\Delta \mathbf{D}^{-1} \mathbf{g}_{1}=\left(\mathbf{D}_{0}^{-1} \mathbf{D}_{0} \mathbf{D}_{1}^{-1}-\mathbf{D}_{0}^{-1} \mathbf{D}_{1} \mathbf{D}_{1}^{-1}\right) \mathbf{g}_{1}
$$

Upon re-written (B-12),

$$
\Delta \mathbf{D}^{-1} \mathbf{g}_{1}=\mathbf{D}_{0}^{-1}\left(\mathbf{D}_{0} \mathbf{D}_{1}^{-1}-\mathbf{D}_{1} \mathbf{D}_{1}^{-1}\right) \mathbf{g}_{1}
$$

From (B-13), the following can also be derived:

$$
\Delta \mathbf{D}^{-1} \mathbf{g}_{1}=\mathbf{D}_{0}^{-1}\left(\mathbf{D}_{0}-\mathbf{D}_{1}\right) \mathbf{D}_{1}^{-1} \mathbf{g}_{1}
$$

From equation (B-2), let $\mathbf{D}_{1}^{-1} \mathbf{g}_{1}=\mathbf{x}_{1}$ and write (B-14) as follows:

$$
\Delta \mathbf{D}^{-1} \mathbf{g}_{1}=\mathbf{D}_{0}^{-1}\left(\mathbf{D}_{0}-\mathbf{D}_{1}\right) \mathbf{x}_{1}
$$


Substituting the definition of $\mathbf{D}_{0}$ and $\mathbf{D}_{1}$ in the (B-15) yields

$$
\Delta \mathbf{D}^{-1} \mathbf{g}_{1}=\mathbf{D}_{0}^{-1}\left[\left(\mathbf{I}-\mathbf{h}_{0} \mathbf{A}_{0}\right)-\left(\mathbf{I}-\mathbf{h} \quad \mathbf{A}_{1}\right)\right] \mathbf{x}_{1}
$$

Re-arranging (B-16) gives us equation (B-17) below

$$
\begin{gathered}
\Delta \mathbf{D}^{-1} \mathbf{g}_{1}=\mathbf{D}_{0}^{-1}\left(\mathbf{I}-\mathbf{h}_{0} \mathbf{A}_{0}-\mathbf{I}+\mathbf{h}_{1} \mathbf{A}_{1}\right) \mathbf{x}_{1} \\
\Delta \mathbf{D}^{-1} \mathbf{g}_{1}=\mathbf{D}_{0}^{-1}\left(\mathbf{h}_{1} \mathbf{A}_{1}-\mathbf{h}_{0} \mathbf{A}_{0}\right) \mathbf{x}_{1}
\end{gathered}
$$

Adding and subtracting the same term $\mathbf{h}_{0} \mathbf{A}_{1}$ from (B-17),

$$
\Delta \mathbf{D}^{-1} \mathbf{g}_{1}=\mathbf{D}_{0}^{-1}\left(\mathbf{h}_{1} \mathbf{A}_{1}-\mathbf{h}_{0} \mathbf{A}_{0}+\mathbf{h}_{0} \mathbf{A}_{1}-\mathbf{h}_{0} \mathbf{A}_{1}\right) \mathbf{x}_{1}
$$

Re-arranging the resulting equation (B-18) gives,

$$
\Delta \mathbf{D}^{-1} \mathbf{g}_{1}=\mathbf{D}_{0}^{-1}\left(\Delta \mathbf{h} \mathbf{A}_{1} \mathbf{x}_{1}+\mathbf{h}_{0} \Delta \mathbf{A} \mathbf{x}_{1}\right)
$$

Finally substituting (B-10) and (B-19) into (B-8) yields the following:

$$
\Delta \mathbf{x}=\mathbf{D}_{0}^{-1}\left(\Delta \mathbf{s f}_{1}+\mathbf{s}_{0} \Delta \mathbf{f}+\Delta \mathbf{e}\right)+\mathbf{D}_{0}^{-1}\left(\Delta \mathbf{h} \mathbf{A}_{1} \mathbf{x}_{1}+\mathbf{h}_{0} \Delta \mathbf{A} \mathbf{x}_{1}\right)
$$

Letting $\mathbf{D}_{0}^{-1}=\mathbf{R}_{0}$ we can derive equation (9b) in the text:

$$
\Delta \mathbf{x}=\mathbf{R}_{0} \Delta \mathbf{s}_{1}+\mathbf{R}_{0} \mathbf{s}_{0} \Delta \mathbf{f}+\mathbf{R}_{0} \Delta \mathbf{e}+\mathbf{R}_{0} \Delta \mathbf{h} \mathbf{A}_{1} \mathbf{x}_{1}+\mathbf{R}_{0} \mathbf{h}_{0} \Delta \mathbf{A} \mathbf{x}_{1}
$$

Using Paasche weighting the derivation of equation (9a) is also analogous to (B-21).

\section{Appendix $\quad$ B: Price Adjustment Procedure}

The examination of the effects of structural changes in the economy requires an interpemporal comparison by handling changes in price levels. Using two input-output matrices for different years in current prices, we attempt to adjust coefficient matrices for $s$ based matrices to the base year $t(s>t)$ (e.g. see Günlük-Şenesen and Küçükçifçi, 1994). The deflating procedure involves expressing $\mathbf{A}_{\mathrm{s}}$, the matrix of technical coefficients, in the price of the year $t$. We define $\mathbf{A}_{\mathrm{s}}{ }_{\mathrm{s}}$ as $\mathbf{A}_{\mathrm{s}}$ deflated with year $s$ prices, so that

$$
\mathbf{A}_{\mathrm{s}}{ }^{\mathrm{t}}=\mathbf{P}_{\mathrm{s}}{ }^{-1} \mathbf{A}_{\mathrm{s}} \mathbf{P}_{\mathrm{s}}
$$

where $\mathbf{P}_{\mathrm{s}}$ is the diagonal matrix of industrial price indices capturing changes in price levels from year $t$ to $s$. From A-1, the typical element of $\mathbf{A}_{\mathrm{s}}{ }^{\mathrm{t}}$ is 


$$
a_{s, i j}^{t}=\frac{x_{s, i j}}{x_{s, j}} \frac{P_{s, j}}{P_{s, i}}
$$

where $P_{s, i}$ and $P_{s, j}$ are changes in industrial price indices of sector $i$ and sector $j$ from year $t$ to year $s$ respectively, and the $\left(P_{s, j} / P_{s, i}\right)$ term on the right-hand side captures the relative prices from year $t$ to year $s$.

\section{Appendix C: Sectoral Aggregation}

The Turkish input-output tables before 1996 comprised sixty-four sectors. The available latest table, on the other hand, possesses 97 sectors. Due to lack of the data on the price indices at this aggregation level, we aggregated sectors to the 24 sectors. However, it has been necessary to aggregate them further to 7 sectors to examine some hypothesis advanced in the text. In what follows, we first present the aggregation of the $64 \times 64$ input-output table to the $24 \times 24$ one, then introduce the smaller table with further aggregation to 7 sectors.

\section{The sectors in the $24 \times 24$ tables}

\section{SECTORS}

1- Agriculture

2- Mining

3- Food-Beverage

4- Textiles

5- Wood-Furniture

6- Paper-Printing

7-Chemicals

8- Oil-Refining

9- Rubber-Plastics

10- Glass-Cement

11- Iron-Steel

12- Metal Product

13-Machinery

14- Electrical-Machinery

15- Transportation-Vehicles

16- Other manufacturing

17- Utilities

18- Construction

19- Trade

20- Transportation Service

21- Banking and Insurance

22- Personal Services

23- Public Services

24- Housing $\begin{array}{rr}\text { Sector numbers in } & \text { Sector numbers in } \\ \text { the } 64 \times 64 \text { input- } & \text { the } 97 \times 97 \text { input- } \\ \text { output table } & \text { output table }\end{array}$

$\begin{array}{rr}1-4 & 1-7 \\ 5-10 & 8-12 \\ 11-19 & 13-25 \\ 20-24 & 26-32\end{array}$

33-34 and 67

35-37

$39-43$

38

44-45

46-49

50-52

53-54

55-58

59-60

62-66

61 and 68

69-71

72

73-77

$78-83$

84-85

86-95

96

97 


\section{Table 1 Main Macroeconomic Indicators}

\begin{tabular}{llllll}
$1973-76$ & $1977-80$ & $1981-83$ & $1984-88$ & $1989-93$ & $1994-96$ \\
\hline
\end{tabular}

Real GDP growth rate

Savings/GDP

Investment/GDP

Exports/GDP

Imports/GDP

Total PSBR/GDP ${ }^{1}$

Main prices

Inflation (average in \%)

Real exchange rate ${ }^{2}(\%$ average)

Real interest rate (average in \%)

\section{2 \\ (Period Average in \%)}

20.8

21.4

3.7

9.2

$\begin{array}{rrrrr}1.3 & 4.0 & 5.9 & 5.2 & 3.1 \\ 17.3 & 17.3 & 21.7 & 21.9 & 21.4 \\ 22.5 & 18.5 & 22.3 & 23.7 & 23.9 \\ 3.3 & 7.8 & 11.5 & 9.1 & 13.3 \\ 8.6 & 13.7 & 16.4 & 14.7 & 21.1 \\ 6.9 & 4.1 & 4.7 & 9.1 & 7.6\end{array}$

${ }^{1} C A B$ and $P S B R$ respectively stand for current account balance and public sector borrowing requirement.

${ }^{2}$ Calculated as $e\left(P^{*} / P\right)$, where $e$ is the nominal exchange rate, $P^{*}$ and $P$ are the consumer price indices of the USA and Turkey respectively. Negative numbers indicate the overvaluation of currency, and vice versa.

${ }^{3}$ This aggregated sector includes agriculture, mining, energy and services.

Sources: Economic and Social Indicators (1950-1998), Ankara: State Planning Organisation, 1997, and F. Özatay (2000) “A Quarterly Macroeconometric Model for a Highly İnflationary and Indebted Country: Turkey”, Economic Modelling 17: 1-11.

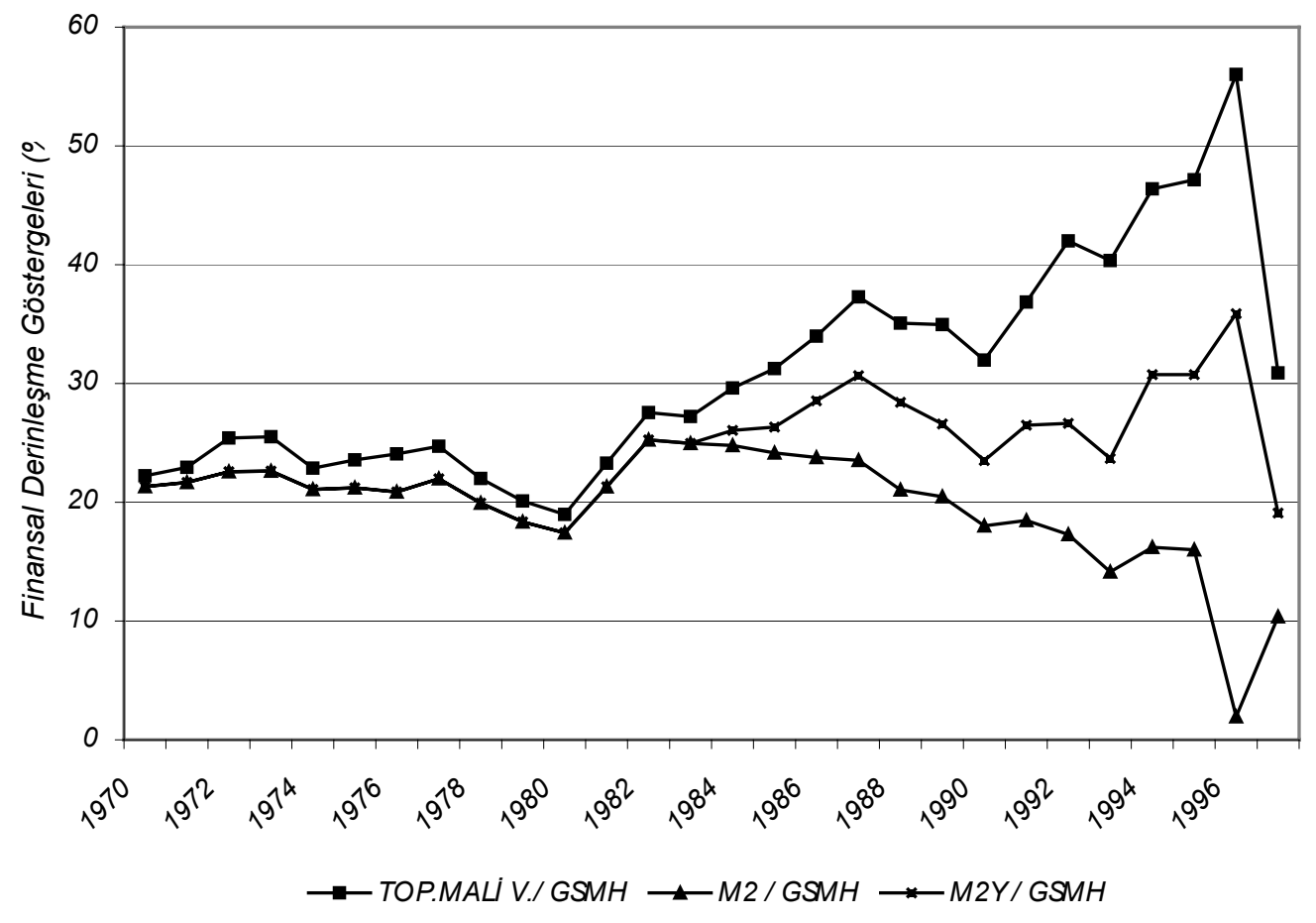

Figure 1 Total Financial Assets / GNP 
Table 2 - The Shares \& Growth Rates of Sectoral Output (\%)

\begin{tabular}{|c|c|c|c|c|}
\hline & \multicolumn{2}{|c|}{ Output Growth } & \multicolumn{2}{|c|}{ Shares of Sectoral Output } \\
\hline & $\begin{array}{c}\text { Overall } \\
\text { Period }\end{array}$ & Annual $^{*}$ & Initial Year & Terminal Year \\
\hline \multicolumn{5}{|c|}{ 1973-1996 } \\
\hline Agriculture & 240.2 & 5.5 & 21.4 & 17.2 \\
\hline Mining & 133.8 & 3.8 & 1.1 & 0.62 \\
\hline Manufacturing & 330.5 & 6.6 & 38.0 & 38.5 \\
\hline Non-Financial Services & 383.4 & 7.1 & 37.3 & 42.5 \\
\hline Financial Services & 130.0 & 3.7 & 2.2 & 1.2 \\
\hline TOTAL & 324.2 & 6.5 & 100 & 100 \\
\hline \multicolumn{5}{|c|}{ 1973-1985 } \\
\hline Agriculture & 51.9 & 3.5 & 21.4 & 15.9 \\
\hline Mining & 64.0 & 4.2 & 1.1 & 0.9 \\
\hline Manufacturing & 117.7 & 6.7 & 38.0 & 40.39 \\
\hline Non-Financial Services & 125.0 & 7.0 & 37.3 & 40.9 \\
\hline Financial Services & 75.1 & 4.8 & 2.2 & 1.9 \\
\hline TOTAL & 104.8 & 6.2 & 100 & 100 \\
\hline \multicolumn{5}{|c|}{ 1985-1990 } \\
\hline Agriculture & 72.0 & 11.45 & 15.9 & 18.0 \\
\hline Mining & 53.2 & 8.9 & 0.89 & 0.9 \\
\hline Manufacturing & 36.4 & 6.41 & 40.4 & 36.3 \\
\hline Non-Financial Services & 60.5 & 9.93 & 40.9 & 43.3 \\
\hline Financial Services & 12.5 & 2.38 & 1.9 & 1.4 \\
\hline TOTAL & 51.7 & 8.68 & 100 & 100 \\
\hline \multicolumn{5}{|c|}{ 1990-1996 } \\
\hline Agriculture & 30.3 & 4.5 & 18.0 & 17.2 \\
\hline Mining & -6.9 & -1.2 & 0.9 & 0.6 \\
\hline Manufacturing & 44.9 & 6.4 & 36.3 & 38.5 \\
\hline Non-Financial Services & 33.9 & 5.0 & 43.3 & 42.5 \\
\hline Financial Services & 16.8 & 2.6 & 1.4 & 1.2 \\
\hline TOTAL & 36.6 & 5.3 & 100 & 100 \\
\hline
\end{tabular}

*Annual growth rates are calculated as geometric average of each period. 
Table 3a - The Source of Changes in Gross Output: Paasche Weighting (\%)

\begin{tabular}{|c|c|c|c|c|c|}
\hline & $\begin{array}{r}\text { Final } \\
\text { demand }\end{array}$ & $\begin{array}{l}\text { Exports } \\
\text { demand }\end{array}$ & $\begin{array}{r}\text { Import } \\
\text { substitution } \\
\text { in final } \\
\text { demand } \\
\end{array}$ & $\begin{array}{r}\text { Import } \\
\text { substitution } \\
\text { in } \\
\text { intermediate } \\
\text { goods } \\
\end{array}$ & $\begin{array}{l}\text { Changes in } \\
\text { Technology }\end{array}$ \\
\hline \multicolumn{6}{|c|}{ 1973-1996 } \\
\hline Agriculture & 91.7 & 12.9 & 2.3 & -2.2 & -4.7 \\
\hline Mining & 106.4 & 30.7 & 8.2 & -42.1 & -3.2 \\
\hline Manufacturing & 69.0 & 27.4 & 4.2 & -1.7 & 1.1 \\
\hline Non-Financial services & 83.1 & 14.8 & 0.4 & -0.2 & 1.8 \\
\hline Financial services & 116.5 & 23.8 & 1.9 & -1.3 & -40.9 \\
\hline TOTAL & 79.4 & 19.5 & 2.2 & -1.3 & 0.1 \\
\hline \multicolumn{6}{|c|}{ 1973-1985 } \\
\hline Agriculture & 101.5 & 22.9 & 2.8 & -2.0 & -25.2 \\
\hline Mining & 102.5 & 49.6 & -1.2 & -78.3 & 27.3 \\
\hline Manufacturing & 63.1 & 32.1 & 2.1 & 0.5 & 2.1 \\
\hline Non-Financial services & 82.7 & 16.4 & 0.2 & -0.1 & 0.8 \\
\hline Financial services & 92.9 & 32.9 & 1.5 & -1.0 & -26.3 \\
\hline TOTAL & 76.6 & 24.3 & 1.3 & -0.6 & -1.7 \\
\hline \multicolumn{6}{|c|}{ 1985-1990 } \\
\hline Agriculture & 84.1 & 2.9 & 5.3 & -3.2 & 11.0 \\
\hline Mining & -1.7 & -0.3 & 115.4 & 7.0 & -20.4 \\
\hline Manufacturing & 59.4 & 3.4 & 23.7 & -7.4 & 21.0 \\
\hline Non-Financial services & 84.0 & 3.7 & 2.0 & -0.6 & 10.9 \\
\hline Financial services & 294.7 & -13.7 & 23.2 & -6.7 & -197.5 \\
\hline$T O T A L$ & 77.2 & 3.3 & 10.0 & -3.1 & 12.6 \\
\hline \multicolumn{6}{|c|}{ 1990-1996 } \\
\hline Agriculture & 94.9 & 23.3 & 5.2 & -7.6 & -15.9 \\
\hline Mining & -252.4 & -116.7 & 94.0 & 116.4 & 208.8 \\
\hline Manufacturing & 79.9 & 39.1 & 2.3 & -10.1 & -11.2 \\
\hline Non-Financial services & 76.1 & 24.9 & 0.3 & -1.3 & 0.0 \\
\hline Financial services & 149.2 & 62.5 & 2.5 & -80.1 & -106.2 \\
\hline TOTAL & 81.6 & 31.5 & 1.8 & -6.5 & -8.4 \\
\hline
\end{tabular}


Table 3b - The Source of Changes in Gross Output: Laspeyres Weighting (\%)

\begin{tabular}{|c|c|c|c|c|c|}
\hline & $\begin{array}{r}\text { Final } \\
\text { demand }\end{array}$ & $\begin{array}{l}\text { Exports } \\
\text { demand }\end{array}$ & $\begin{array}{r}\text { Import } \\
\text { substitution } \\
\text { in final } \\
\text { demand }\end{array}$ & $\begin{array}{r}\text { Import } \\
\text { substitution } \\
\text { in } \\
\text { intermediate } \\
\text { goods }\end{array}$ & $\begin{array}{l}\text { Changes in } \\
\text { Technology }\end{array}$ \\
\hline \multicolumn{6}{|c|}{ 1973-1996 } \\
\hline Agriculture & 99.8 & 19.5 & 11 & -8.9 & -21.4 \\
\hline Mining & 165.4 & 71.7 & 62.5 & -163.6 & -36.0 \\
\hline Manufacturing & 61.7 & 28 & 13.0 & -7.8 & 5.2 \\
\hline Non-Financial services & 77.0 & 14.1 & 1.4 & -1.0 & 8.5 \\
\hline Financial services & 208.3 & 56.3 & 20.6 & -17.8 & -167.4 \\
\hline TOTAL & 76.2 & 21.0 & 7.9 & -5.8 & 0.7 \\
\hline \multicolumn{6}{|c|}{ 1973-1985 } \\
\hline Agriculture & 118.8 & 30.7 & 5.6 & -2.1 & -53.0 \\
\hline Mining & 157.6 & 68.1 & -16.3 & -285.1 & 175.6 \\
\hline Manufacturing & 60.5 & 31.3 & 3.5 & 1.4 & 3.2 \\
\hline Non-Financial services & 81.8 & 16.3 & 0.4 & -0.2 & 1.7 \\
\hline Financial services & 115.7 & 40.3 & 2.7 & -7.7 & -51.1 \\
\hline TOTAL & 77.7 & 25.0 & 2.2 & -1.7 & -3.1 \\
\hline \multicolumn{6}{|c|}{ 1985-1990 } \\
\hline Agriculture & 78.0 & 2.7 & 6.9 & -4.9 & 17.3 \\
\hline Mining & 25.5 & -0.3 & 88.9 & 4.2 & -18.3 \\
\hline Manufacturing & 51.9 & 3.2 & 26.3 & -12.1 & 30.7 \\
\hline Non-Financial services & 79.5 & 3.5 & 1.9 & -0.8 & 15.9 \\
\hline Financial services & 331.6 & -9.6 & 46.7 & -20.0 & -248.8 \\
\hline TOTAL & 71.9 & 3.2 & 11.0 & -5.0 & 18.9 \\
\hline \multicolumn{6}{|c|}{ 1990-1996 } \\
\hline Agriculture & 102.4 & 28.4 & 7.2 & -11.7 & -26.3 \\
\hline Mining & -397.8 & -173.1 & 108.7 & 190.1 & 372.1 \\
\hline Manufacturing & 86.0 & 42.4 & 3.8 & -13.9 & -18.3 \\
\hline Non-Financial services & 77.1 & 25.7 & 0.6 & -2.1 & -1.3 \\
\hline Financial services & 185.1 & 77.9 & 4.7 & -14.8 & -152.8 \\
\hline TOTAL & 86.3 & 34.2 & 2.9 & -9.2 & -14.2 \\
\hline
\end{tabular}

